\title{
"Losanga" decorated imitations of italic late republican black gloss tableware from South-Western Iberia: A multi-analytical/ microchemical characterization is
}

\author{
Nick Schiavon $^{\mathrm{a}, *}$, Vincenzo Soria ${ }^{\mathrm{b}}$, Ana Margarida Arruda ${ }^{\mathrm{b}}$, Massimo Beltrame ${ }^{\mathrm{a}}$, José Mirão ${ }^{\mathrm{a}}$ \\ a Hercules Laboratory, University of Évora, Évora, Portugal \\ b UNIARQ Centro de Arqueologia, University of Lisbon, Lisbon, Portugal
}

\section{A R T I C L E I N F O}

\section{Article history:}

Received 15 August 2015

Accepted 13 October 2015

Available online 20 October 2015

\section{Keywords:}

Roman pottery

SW Iberia

Portable XRF

BSEM + EDS

XRD

Italic black gloss tableware

\begin{abstract}
A B S T R A C T
The micro-chemical/mineralogical composition of samples of grey-paste imitations of Italic Late Republican black gloss tableware displaying a particular kind of lozenge-shaped decoration ("Losanga pottery") from Portuguese and Spanish archaeological sites in SW Iberia has been analysed by BSEM + EDS, $\mu$ XRD, Powder XRD, Portable $\mathrm{XRF}$ and $\mu$ Raman spectroscopy. "Losanga" decorated ceramics have been found throughout the Western Mediterranean. Most of the sherds display a green-brown to greyish-black engobe at the surface resembling the gloss found in Attic pottery from Classical Greece. The overall chemical, mineralogical and fossiliferous homogeneities of the ceramic paste show common features (low K-feldspar/plagioclase ratio, high Ca content, abundance of well-preserved fragments of foraminifera microfossils) that indicate low firing conditions in the kiln ranging from 650 to $900{ }^{\circ} \mathrm{C}$. With respect to the ceramic body, analytical results confirm an enrichment in the surface gloss layer of iron, potassium and aluminium and a depletion in silicon and calcium; the very fine grain size of the surface coating suggests elutriation of iron oxide-rich clays as confirmed by the presence of magnetite, maghemite and goethite in $\mu$-XRD scan. Chemical and mineralogical data also suggest that the firing process was performed in a $600-850^{\circ} \mathrm{C}$ temperature range, adopting the well-known technique of alternating oxidizing and reducing firing conditions largely employed at the time. The analytical results, while compatible with the archaeological hypothesis of a common provenance of the raw materials for pottery production from the Guadalquivir valley workshops cannot be considered conclusive due to the similarity in the geological substrate in the two SW Iberian regions under study.
\end{abstract}

(c) 2015 Elsevier B.V. All rights reserved.

\section{Introduction}

In the study of Roman ceramics and pottery materials, microanalytical techniques combining chemical, microscopical and mineralogical analyses have proved very useful to shed light on raw material provenance and production technology [1-11]. Due to their widespread and ubiquitous distribution across the entire geographical width of the Roman influenced territories, amphorae fragments have received the most attention by researchers. In terms of socio-historical significance, though, tableware pottery production, albeit less studied, is of no less importance due to its wide distribution in the Mediterranean and because it may provide precious information on common trade routes and imported technologies across the Roman Empire [3,12-17].

With the term Italic black gloss ware (also known as Ceramica Campana, or Céramica Campaniense or "Ceramique Campanienne"

\footnotetext{
is Selected papers presented at TECHNART 2015 Conference, Catania (Italy), April 27-30, 2015.

* Corresponding author.

E-mail address: schiavon@uevora.pt (N. Schiavon).
}

according to its geographical distribution) archaeologists identify a specific group and type of tableware production developed between the IV and I century BC mainly in the Italic peninsula characterized by a red, creamy or greyish clay ceramic paste often associated with a black thin superficial engobe/gloss layer [3,12,15,17-19]. During the 2nd and 1st century BC, the massive commercialization of Italic black gloss tableware all around the Mediterranean basin led to imitative processes embedded with social and economic meanings in different regions of the Roman territories including SW Iberia [15,17]. These ceramics have been typologically regarded as tableware "imitations" of the Italic black gloss prototypes, supposed to be locally (in the sense of not imported from the Italic Peninsula) produced during the embryonic phase of interaction [15]. In fact, the craft imitative phenomenon during the Late Republican period in the provincial contexts is supposed to be the consequence of processes driven by the imports of exogenous goods stored in amphorae. Similarly, the growth of tableware imitation is due to the imports of Italic black gloss tableware during the last two centuries before the Common Era. Within the Italic black gloss production, a special typology of high socio-historical significance is represented by the so-called "Losanga-style" tableware, 
characterized by the presence of a decoration of stamped arcs joining four trefoils (Fig. 1). It is generally accepted that the "Losanga" decoration in pottery objects appeared in the 1 st century BC [14] and had a major production centre in the Roman colony of Cales, in the northern part of modern Campania region in Italy [20,21]; "Losanga" pottery objects have been found throughout the Western Mediterranean including sites on the Atlantic African Coast [22]. In this study, samples of "Losanga" tableware from four archaeological sites in Southern/Central Portugal (Faro, Castro Marim, Monte Molião and Santarém) dated from the middle of the 1st century BC to the second half of the 1st century AD [17,19] and from 3 sites in the Seville area (Seville: Patio de Banderas; Italica: Pajar de Artillo; Orippo: Cortijo de Tixe) in the Andalusian region (Southern Spain) dated from the 1st century BC [12,16, 23] were selected for microchemical, microscopical and mineralogical analyses (Figs. 1, 2). A common feature of both Andalusian and Portuguese sites (which explains their role as important consumption centres of the time) lies in their proximity to the sea and to wellestablished ancient fluvial routes (respectively along the Guadalquivir, Tagus and Guadiana river valleys). The Guadalquivir area has long been recognized as an important centre for ceramic production $[10,13$, 23,24 ] as evidenced by the identification of several ceramic workshops with raw materials (clays and temper) for pottery manufacturing coming from the Quaternary fluvial sedimentary deposits of the Guadalquivir River. The importance of the Guadalquivir fluvial valley as a major ceramic production area in the Baetica province of the Hispania Peninsula during Roman occupation has been recently confirmed also by archaeometric analytical data on Haltern 70 amphorae [9]. It is worth noting that the current archaeological investigation in the Guadalquivir valley has not yet recognized the production of the tableware typology investigated in the current study. This state of affairs has led archaeologists to postulate a predominant unidirectional East to West flux of "Losanga" tableware produced in the Guadalquivir area from Baetic to Lusitania. In this vein, the assumption of a shared origin of the typologically similar "Losanga" tableware pottery fragments found in Portuguese sites with the Andalusian ones, though, has, so far, been based only on ceramological evidences [12] as well as on a sort of a "dependency" in terms of dynamism in the distribution of goods from the Andalusian region [25], following the attribution of a catalyst role to that region as expressed in the concept of the "Círculo del Estrecho" [26]. Major and trace-elements' chemical compositions of potsherds from Roman amphorae in the Sado and Tagus river valley $[4,5]$ have indeed been compared with coeval pottery fragments from the Guadalquivir area: these studies identified similarities but also differences linked to changes in the geological/mineralogical terrain of the raw materials used in pottery manufacturing.

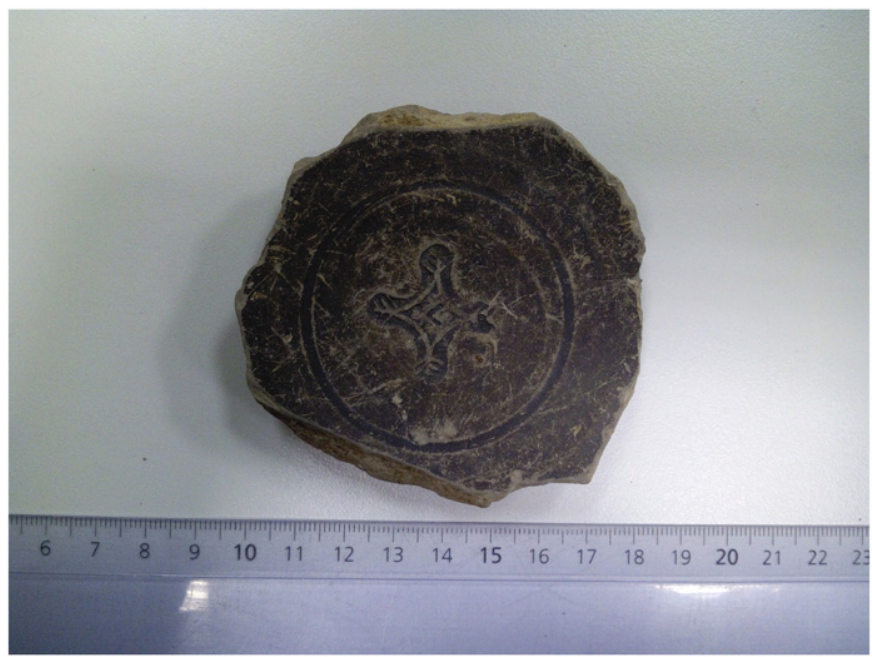

Fig. 1. "Losanga" decorated tableware pottery from SW Iberia.

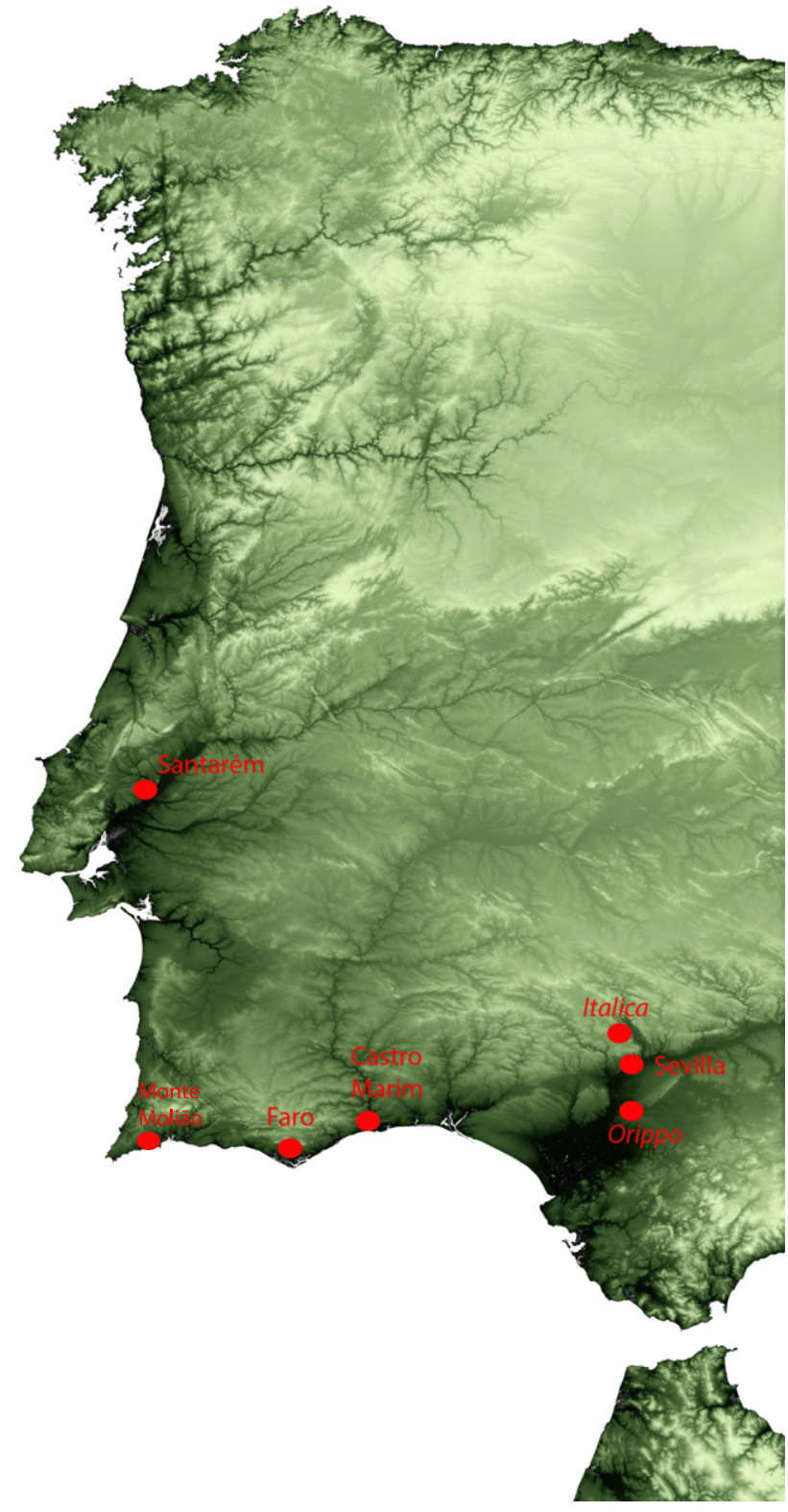

Fig. 2. Sites location map.

The combined micro-analytical approach adopted in this study intends to add important data to the above mentioned debate by providing BSEM + EDS, $\mu$ XRD, PXRF and $\mu$ Raman spectroscopy data to compare the detailed chemical and mineralogical compositions of both the grey paste and the dark surface slip of selected samples from the investigated sites with the aim to establish for the first time a possible correlation between composition and typology, and between the Portuguese and Andalusian assemblages and to determine imported versus local manufacturing practices.

\section{Materials and methods}

31 samples of "Losanga style" tableware pottery (Fig. 1) were selected for analysis by BSEM + EDS, Portable XRF and Micro and Powder XRD. Resin inglobated polished blocks were analysed by BSEM-EDS using a HITACHI S3700N interfaced with a Quanta EDS microanalysis system. The Quanta system was equipped with a Bruker AXS XFlash ${ }^{\circledR}$ Silicon Drift Detector (129 eV Spectral Resolution at FWHM/MnK $\alpha$ ). Standardless PB/ZAF quantitative elemental analysis was performed using the Bruker ESPRIT software. The operating conditions for EDS 
Table 1

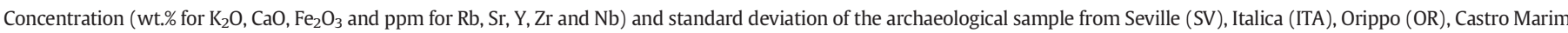
(CM), Santarém (ST), Monte Molião (MM), Faro (FA), and Castro Marim (CM).

\begin{tabular}{|c|c|c|c|c|c|c|c|c|c|c|c|c|c|c|c|c|c|c|}
\hline \multirow[t]{2}{*}{ Samples } & \multicolumn{2}{|l|}{$\mathrm{K}_{2} \mathrm{O}$} & \multicolumn{2}{|l|}{$\mathrm{CaO}$} & \multicolumn{2}{|l|}{$\mathrm{Fe}_{2} \mathrm{O}_{3}$} & \multicolumn{2}{|l|}{ Mn } & \multicolumn{2}{|l|}{$\mathrm{Rb}$} & \multicolumn{2}{|l|}{$\mathrm{Sr}$} & \multicolumn{2}{|l|}{$\mathrm{Zr}$} & \multicolumn{2}{|l|}{ Y } & \multicolumn{2}{|l|}{$\mathrm{Nb}$} \\
\hline & wt.\% & St.dev & wt.\% & St.dev & wt.\% & St.dev & $\mathrm{ppm}$ & St.dev & ppm & St.dev & $\mathrm{ppm}$ & St.dev & ppm & St.dev & ppm & St.dev & ppm & St.dev \\
\hline $2-S V$ & 3.996 & 0.381 & 11.027 & 0.533 & 1.005 & 0.187 & 748.768 & 41.957 & 65.662 & 5.982 & 521.595 & 10.160 & 200.695 & 5.408 & 30.265 & 2.135 & 13.200 & 4.330 \\
\hline $3-S V$ & 3.628 & 0.266 & & 0.336 & 0.959 & 0.247 & 582.624 & 36.581 & & 9.748 & & 30.687 & 197.077 & 4.049 & 27.568 & 2.071 & 0.315 & 3.048 \\
\hline $4-S V$ & 3.194 & 0.247 & 7.960 & 0.302 & 1.948 & 0.149 & 343.873 & 19.519 & 64.752 & 6.729 & 166.078 & 16.447 & 180.967 & 3.959 & 23.520 & 1.426 & 20.997 & 4.877 \\
\hline $5-S V$ & 549 & 0.146 & 5.449 & 0.298 & 2.283 & 0.160 & 1130.729 & 46.999 & 87.731 & 9.706 & 719.726 & 20.857 & 187.300 & 2.411 & 82.373 & 11.179 & 4.237 & 2.420 \\
\hline $6-S V$ & 5.159 & 0.126 & 5.200 & 0.235 & 1.863 & 0.171 & 863.487 & 22.805 & 69.808 & 6.863 & 570.299 & 35.024 & 207.224 & 4.529 & 28.393 & 3.853 & 698 & 2.721 \\
\hline $7-S V$ & 3.098 & 0.113 & 11.165 & 0.315 & 0.918 & 0.294 & 595.597 & 51.398 & 63.038 & 9.329 & 454.909 & 27.059 & 212.681 & 3.417 & 32.929 & 0.830 & 11.517 & 3.445 \\
\hline $8-S V$ & 6.247 & 0.220 & 7.907 & 0.445 & 1.905 & 0.101 & 719.755 & 90.330 & 89.100 & 4.492 & 968.304 & 40.169 & 192.281 & 2.920 & 65.458 & 3.493 & & n.d. \\
\hline $9-\mathrm{SV}$ & 232 & 0.121 & 493 & 0.329 & 1.640 & 0.184 & 785.928 & 14.822 & 4.979 & 8.727 & 38.498 & 15.178 & 2.324 & 2.086 & 34.347 & 1.648 & & 0.956 \\
\hline $10-S V$ & 773 & 0.157 & 6.943 & 0.289 & 2.005 & 0.167 & 498.705 & 34.780 & .573 & 6.553 & .143 & 17.210 & 2.249 & 4.989 & 10.884 & 4.009 & 047 & 4.319 \\
\hline $11-S V$ & 2.716 & 0.194 & 8.501 & 0.218 & 2.268 & 0.114 & 2097.862 & 52.875 & 64.042 & 3.374 & 270.616 & 16.689 & 2.083 & 1.317 & 27.611 & 0.619 & & 2.136 \\
\hline $12-\mathrm{SV}$ & 344 & 0.273 & 6.853 & 0.480 & 2.352 & 0.065 & 03 & 68.340 & 101. & 4.015 & 23 & 15.914 & & 1.249 & 22.723 & 524 & & 1.083 \\
\hline $13-$ ITA & 4.824 & 0.203 & 5.807 & 0.244 & 1.619 & 0.069 & 2576.995 & 59.597 & .940 & 4.900 & .622 & 27.309 & 3.067 & 3.467 & 33.917 & 1.663 & 31 & 3.995 \\
\hline $14-\mathrm{OR}$ & 4.290 & 0.176 & 9.065 & 0.239 & 1.220 & 0.085 & 1249.896 & 48.198 & 73.752 & 3.512 & 2.894 & 15.707 & 4.295 & 1.392 & 26.256 & 0.404 & 775 & 1.523 \\
\hline $15-\mathrm{OR}$ & 5.785 & 0.345 & 8.946 & 0.493 & 0.628 & 0.157 & 930.840 & 31.789 & 54.277 & 5.099 & .518 & 6.327 & & 3.498 & 29.470 & 0.954 & & 2.330 \\
\hline $16-\mathrm{OR}$ & 3.167 & 0.671 & 11.562 & 0.937 & 1.071 & 0.073 & 678 & 39.113 & 561 & 5.742 & 865 & 33.137 & 472 & 3.004 & 34.464 & 2.583 & & 3.196 \\
\hline $17-\mathrm{OR}$ & 4.870 & 0.209 & 7.500 & 0.383 & 1.423 & 0.178 & 460.857 & 41.760 & 80.509 & 6.040 & 514.507 & 11.570 & 185.816 & 3.908 & 32.948 & 3.928 & & 2.797 \\
\hline $18-\mathrm{OR}$ & 5.422 & 0.363 & 5.844 & 0.570 & 1.991 & 0.161 & 704.993 & 7.644 & 80.105 & 9.247 & 545.041 & 7.374 & 201.145 & 2.133 & 32.167 & 1.997 & 7.479 & 2.741 \\
\hline $19-\mathrm{CM}$ & 5.900 & 0.239 & 7.308 & 0.400 & 1.454 & 0.207 & 577.129 & 53.998 & 90.335 & 10.215 & 348.669 & 8.650 & 3.374 & 5.546 & 32.710 & 0.701 & .762 & 4.396 \\
\hline $20-\mathrm{ST}$ & 5.101 & 0.144 & 3.154 & 0.280 & 3.366 & 0.120 & & 25.880 & 227.866 & 10.953 & 142.122 & 11.635 & 173.494 & 2.722 & 31.753 & 0.978 & 12.216 & 2.442 \\
\hline $21-\mathrm{ST}$ & 5.999 & 0.199 & 5.546 & 0.213 & 1.844 & 0.099 & 569.733 & 16.258 & 92.138 & 4.773 & 487.434 & 20.216 & 198.252 & 2.740 & 34.912 & 0.644 & 9.053 & 4.444 \\
\hline $22-\mathrm{ST}$ & 6.535 & 0.212 & 6.303 & 0.233 & 0.704 & 0.252 & 594.721 & 45.356 & 70.909 & 10.791 & 426.652 & 23.258 & 203.796 & 3.129 & 30.085 & 0.213 & 9.340 & 3.313 \\
\hline $23-\mathrm{ST}$ & 5.653 & 0.238 & 5.764 & 0.329 & 1.796 & 0.111 & 708.620 & 49.608 & 88.620 & 7.254 & 338.726 & 14.090 & 182.962 & 5.036 & 28.544 & 1.826 & 16.220 & 4.209 \\
\hline $24-\mathrm{ST}$ & 3.648 & 0.107 & 8.050 & 0.303 & 2.445 & 0.186 & 728.933 & 22.068 & 72.278 & 10.274 & 415.608 & 29.023 & & 1.872 & 31.116 & 1.181 & & 2.876 \\
\hline $25-\mathrm{ST}$ & 3.977 & 0.300 & 9.026 & 0.428 & 1.495 & 0.092 & 773.662 & 37.512 & 83.173 & 4.046 & 380.878 & 8.454 & 186.436 & 4.645 & 26.422 & 1.965 & 19.148 & 4.447 \\
\hline $26-\mathrm{MM}$ & 3.220 & 0.186 & 10.152 & 0.342 & 2.284 & 0.106 & 632.601 & 60.217 & 77.114 & 5.493 & 402.775 & 23.588 & 189.602 & 3.020 & 27.420 & 2.093 & 22.530 & 2.069 \\
\hline $27-\mathrm{MM}$ & 2.447 & 0.138 & 6.864 & 0.265 & 3.294 & 0.150 & 1646.575 & 14.106 & 132.799 & 10.280 & 370.455 & 16.989 & 181.306 & 2.544 & 41.805 & 1.189 & 19.855 & 2.667 \\
\hline $28-F A$ & 7.228 & 0.165 & 5.765 & 0.130 & 1.789 & 0.093 & 957.865 & 21.185 & 73.880 & 4.126 & 561.278 & 12.931 & 200.301 & 4.346 & 32.485 & 1.577 & 11.124 & 3.225 \\
\hline $29-\mathrm{FA}$ & 6.284 & 0.357 & 3.382 & 0.579 & 2.398 & 0.126 & 1404.744 & 39.768 & 89.530 & 6.586 & 463.083 & 12.569 & 200.061 & 2.598 & 39.176 & 1.945 & 11.753 & 1.955 \\
\hline $30-\mathrm{CM}$ & 6.599 & 0.338 & 6.119 & 0.474 & 1.507 & 0.165 & 1017.040 & 46.066 & 79.448 & 6.322 & 527.135 & 21.295 & 191.826 & 1.811 & 31.868 & 4.766 & 14.512 & 3.004 \\
\hline $31-\mathrm{CM}$ & 3.934 & 0.164 & 7.918 & 0.359 & 2.276 & 0.126 & 1999.498 & 85.139 & 63.003 & 3.785 & 345.560 & 10.794 & 232.263 & 2.863 & 34.228 & 1.501 & 40.946 & 1.212 \\
\hline $32-\mathrm{CM}$ & 4.413 & 0.280 & 6.826 & 0.413 & 2.468 & 0.107 & 1245.596 & 59.200 & 68.308 & 4.518 & 414.771 & 8.894 & 205.039 & 4.071 & 30.549 & 0.725 & 18.912 & 3.887 \\
\hline
\end{tabular}

analysis were as follows: BSEM mode (BSEM), $20 \mathrm{kV}$ accelerating voltage, $10 \mathrm{~mm}$ working distance, and $120 \mu \mathrm{A}$ emission current. The detection limits for major elements (>Na) were in the order of $0.1 \mathrm{wt} . \%$.

$\mu$-XRD and Powder XRD (PXRD) were used to identify crystalline phases. A Bruker AXS D8 Discovery XRD with the Da Vinci design with a $\mathrm{Cu} \mathrm{K} \alpha$ source operating at $40 \mathrm{kV}$ and $40 \mathrm{~mA}$ and a lynxeye 1dimensional detector was used. Scans were run from 3 to $75^{\circ} 2 \theta$, with $0.05^{\circ}$ step and $1 \mathrm{~s}$ measuring time by point. PXRD was used for bulk analysis while $\mu$-XRD was used to investigate the black slip. The XRD system was reconfigured and a Goebel mirror and a $300 \mu \mathrm{m}$ beamcollimator were employed.

For major and minor elemental analyses a Portable XRF was used for quick and non-destructive examination. The instrument used was a Brüker TRACER III-SD handheld portable XRF spectrometer equipped with a Rhodium tube. Archaeological samples were analysed six times each with the same analytical condition. Six repetitions were considered sufficient, especially for ceramic samples, to obtain representative results for $\mathrm{K}, \mathrm{Ca}, \mathrm{Fe}, \mathrm{Mn}, \mathrm{Rb}, \mathrm{Sr}, \mathrm{Zr}, \mathrm{Y}$ and $\mathrm{Nb}$ and to reduce problems related to grain size and mineralogy [7]. Flat (or almost flat) sections were selected for analysis to avoid interference caused by the presence of a slip, surface contaminant [8] and/or surface roughness [7]. Operating conditions were $40 \mathrm{kV}$ and $35 \mu \mathrm{A}$ using a filter (green filter, $12 \mathrm{~mm} \mathrm{Al}+1 \mathrm{~mm} \mathrm{Ti}+6 \mathrm{~mm} \mathrm{Cu}$ ) with 300 s live-time-counts. Characteristic radiations were collected by a silicon drift detector (SDD) with an energy resolution of $149.68 \mathrm{eV}$ at $\mathrm{Mn} \mathrm{K} \alpha \mathrm{FWHM}$. The beam spot is elliptical in shape with dimension 3 by $4 \mathrm{~mm}\left(7 \mathrm{~mm}^{2}\right)$. The equipment also possesses a camera, allowing the visualization of the analysed area and thus the capture of the image and the spot of analysis. S1 PXRF software (v. 3.8.30) was used to record the spectra, and ARTAX software (v. 5.3.0.0) for the first spectra evaluation and for the selection of the reference standards.

Quantifications were performed converting count rates as the ratio of the K $\alpha$ Rh peak following the guideline of Speakman and Shackley
[27] and using a "calibration macro" developed by Bruker, loaded in Excel environment. The calibration macro allows the selection of the spectra lines, in this case $\mathrm{K} K \alpha, \mathrm{Ca} K \alpha, \mathrm{Mn} \mathrm{K} \alpha$, Fe K $\alpha$, Rb $\mathrm{K} \alpha$, Sr K $\alpha, \mathrm{Y}$ $\mathrm{K} \alpha, \mathrm{Zr} \mathrm{K} \alpha$ and $\mathrm{Nb} K \alpha$, and of inter-element corrections that compensate for the complex X-Ray physics occurring during excitation, notably matrix effects caused by inter element excitation and self absorption. To create the calibration 15 reference materials certified by the U.S. Geological Survey (USGS) were used; 7 were micro-analytical reference samples mounted in epoxy resin (BIR-1G, GSC-1G, GSE-1G, NKT-1G, BCR-2G, BHVO-2G, TB-1G) and 8 were powdered reference samples (BCR-2, W-2A, GSP-2, SBC-1, AGV-2, COQ-1, QLO-1A, SGR-1B, BCR-2)

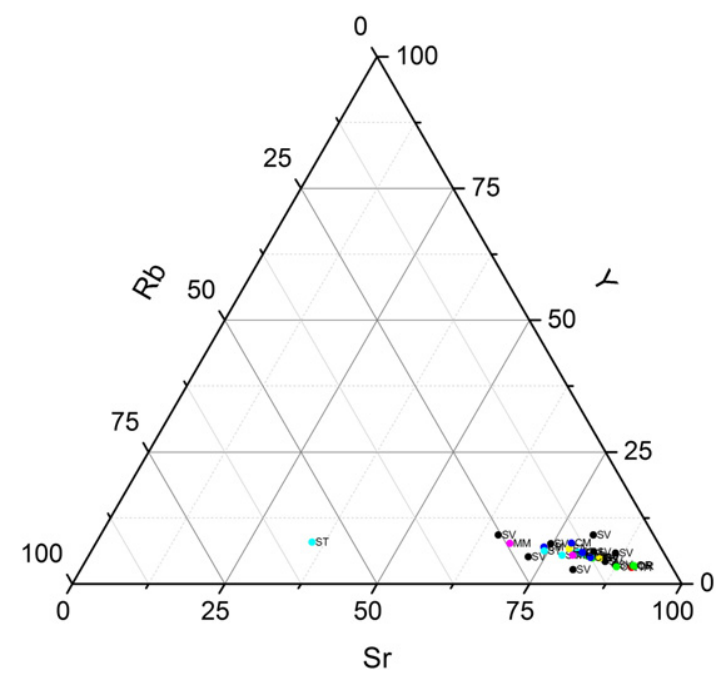

Fig. 3. Portable XRF data. Ternary diagram Rb-Y-Sr. All samples (but one from Santarem ST20) show similar compositions. 


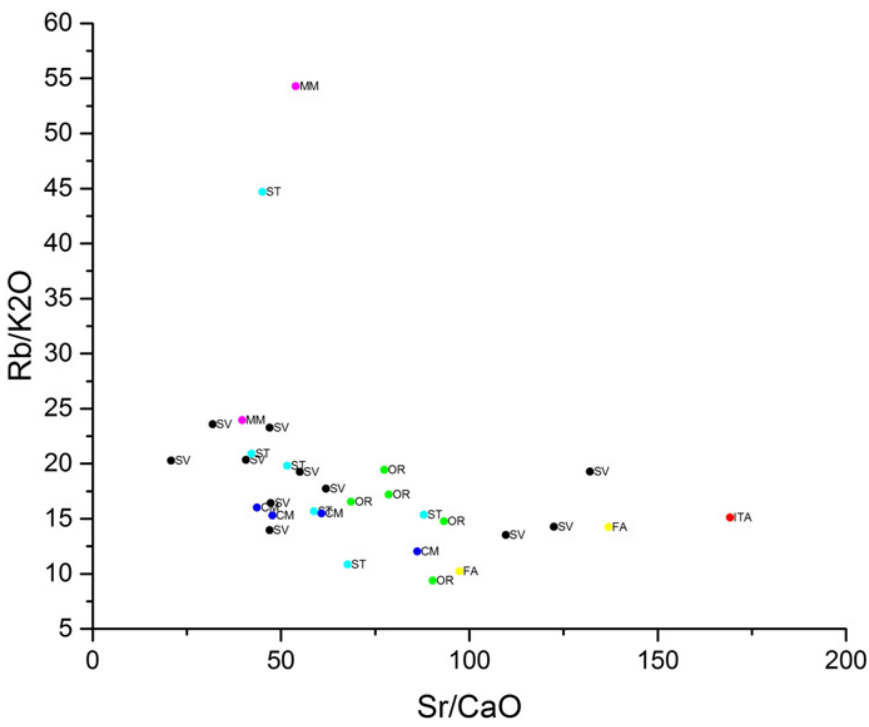

Fig. 4. Portable XRF data. Binary diagram $\mathrm{Rb} / \mathrm{K}_{2} \mathrm{O}-\mathrm{Sr} / \mathrm{CaO}$.

transformed into pressed pellets of $4 \mathrm{~mm}$ each. Previous studies on obsidian demonstrated that powdered and solid reference samples can be used for empirical calibration and data checking. To evaluate the accuracy of the calibration each of the 15 reference standard materials were measured six times and concentrations were calculated using the calibration. For each element the relative standard deviations (\%RSDs) were plotted against certified values [28] showing that as concentration decreases, \%RSD increases. For the chemical elements under consideration \%RSDs obtained were higher than $20 \%$ for concentrations: $\mathrm{K}_{2} \mathrm{O}<0.626$ wt.\%; $\mathrm{Mn}<176$ ppm; $\mathrm{Rb}<4.92 \mathrm{ppm} ; \mathrm{Sr}<32.3$ ppm; $\mathrm{Y}<4.8 \mathrm{ppm} ; \mathrm{Zr}<100$ ppm; and $\mathrm{Nb}<7.9$ ppm. For $\mathrm{CaO}$ and $\mathrm{Fe}_{2} \mathrm{O}_{3}$ \%RSD is less than $10 \%$.

Micro-Raman spectroscopy was used to further complement BSEM + EDS and $\mu$-XRD in investigating the surface black gloss. Two different modes of investigation were used: a) laser beam focused on powdered engobe material obtained by carefully scratching the surface of selected samples and b) laser beam focused directly on the black surface of the sherds. The RAMAN used was an HORIBA Xplora with an Olympus BX41 microscope; the laser was a He-Ne laser operating at $638 \mathrm{~nm}$; two objectives of $10 \times$ and $100 \times$ were used to focus the laser beam on the samples. The backscattered light was dispersed by using a grating of 600 lines $/ \mathrm{mm}$ with an exposure time of $5 \mathrm{~s}$ with 10 scans, and 1200 lines/mm with an exposure time of $10 \mathrm{~s}$ with 15 scans

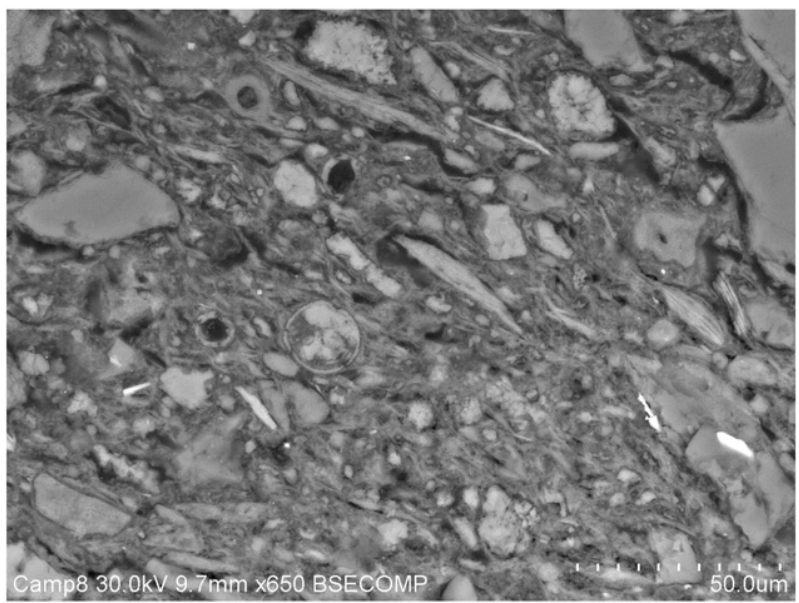

Fig. 5. BSEM + EDS ceramic paste. General view of ceramic paste from Patio de Banderas site (Seville) showing bimodal grain size distribution in ceramic microfabric. Note abundance of calcareous microfossil fragments.

to get sufficiently informative spectra. The sample viewing system consisted of a colour television camera attached to the microscope. After each spectrum had been recorded, a visual inspection was performed in order to detect any superficial change caused by the laser. The HORIBA LabSpec Suite package was used for spectra acquisition and manipulation; the obtained spectra were identified through a comparison with the library of standard spectra of the software or with the reference spectra in the literature.

\section{Results and discussion}

\subsection{X-ray fluorescence}

Chemical data obtained by PXRF on 31 samples, 17 from Spain (11 from Patio de Banderas, 1 from Pajar de Artillo, 5 from Cortijo de Tixe) 14 from Portugal ( 6 from Santarém, 4 from Castro Marim, 2 from Faro and 2 from Monte Molião) are presented in Table 1. Notwithstanding the fact that the main elements present were known to be $\mathrm{Si}$ and $\mathrm{Al}$ coming from the alumino-silicate fraction of the clays and sands (quartz, phyllosilicates and feldspars: see XRD section below) used in ceramic manufacturing, for the purpose of comparing the composition of the potsherds from Spanish and Portuguese; selected elements for analysis were $\mathrm{Ca}, \mathrm{K}$, Fe (expressed in oxides \%) and $\mathrm{Mn}, \mathrm{Rb}, \mathrm{Sr}, \mathrm{Y}, \mathrm{Zr}$ and $\mathrm{Nb}$ (expressed in ppm). Of the selected elements, $\mathrm{CaO}$ is the most abundant ranging from 3.18\% (sample ST20 from Santarém) to 12.18\%

Table 2

XRD Results.

\begin{tabular}{|c|c|c|c|c|c|c|c|c|c|c|c|c|c|c|c|}
\hline & SEV2 & SEV4 & SEV5 & SEV7 & SEV10 & SEV11 & ITA12 & CM18 & ST19 & ST20 & ST21 & ST23 & MM26 & FA29 & CM32 \\
\hline Quartz & +++ & +++ & +++ & +++ & +++ & +++ & +++ & +++ & +++ & +++ & +++ & +++ & +++ & +++ & +++ \\
\hline Plagioclase & $+/++$ & $+/++$ & $+/++$ & ++ & $+/++$ & ++ & $+/++$ & $+/++$ & ++ & ++ & $+/++$ & $+/++$ & $+/++$ & $+/++$ & $+/++$ \\
\hline K-feldspar & $+/++$ & $+/++$ & $+/++$ & $+/++$ & $+/++$ & $+/++$ & ++ & + & + & & $+/++$ & $+/++$ & $+/++$ & $+/++$ & $+/++$ \\
\hline Feldspathoids & - & - & - & - & - & - & - & - & - & & - & - & - & - & - \\
\hline Calcite & +++ & +++ & +++ & +++ & +++ & +++ & +++ & ++ & ++ & +++ & +++ & +++ & +++ & +++ & +++ \\
\hline Dolomite & ++ & ++ & $\mathrm{vtg} / ?$ & $\mathrm{vtg} / ?$ & ++ & ++ & $\mathrm{vtg} / ?$ & & & $+/++$ & $\mathrm{vtg} / ?$ & + & ++ & ++ & $\mathrm{vtg} / ?$ \\
\hline Illite & ++ & ++ & ++ & ++ & ++ & ++ & ++ & ++ & ++ & ++ & ++ & ++ & ++ & ++ & ++ \\
\hline Rutile & & & & & & & & $\mathrm{vtg}$ & + & & & & & & \\
\hline Diopside & - & - & - & + & - & - & - & & & & - & - & - & - & - \\
\hline Analcime & - & - & - & - & - & - & - & & & & - & - & - & - & - \\
\hline Hematite & - & - & vtg & - & - & - & - & + & & & $+/ \mathrm{vtg}$ & - & - & - & $+/ v \operatorname{tg}$ \\
\hline Smectite & - & - & - & - & + & - & - & & & & - & - & + & - & - \\
\hline Maghemite & - & - & - & - & - & - & - & & & & - & - & - & $+/ \mathrm{vtg}$ & $+/ \mathrm{vtg}$ \\
\hline Amphibole & - & - & $?$ & - & - & - & - & & & & - & - & - & - & - \\
\hline
\end{tabular}

+++ : abundant, ++ : present, + small amount, vtg: traces, ? doubts in presence, $-:$ undetected.

Notes:

In sample 26, the smectite pattern is, in fact, the smectite-chlorite (PDF 07-0027) pattern. 


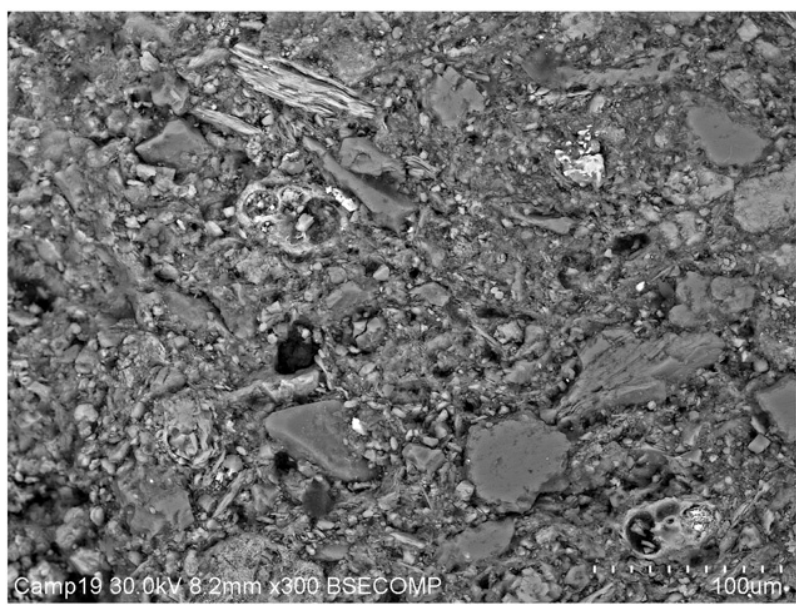

Fig. 6. BSEM + EDS ceramic paste. General view of ceramic paste showing bimodal size in ceramic microfabric.

in sample SEV3 in Patio de Banderas site. According to the classification proposed by Maniatis \& Tite [29] which sets $6 \%$ in weight of $\mathrm{CaO}$ as the percentage threshold to distinguish between calcareous and noncalcareous ceramics, 13 out of 17 Spanish samples and 9 out of 13 samples from Portugal can be considered as calcareous. Variations in $\mathrm{CaO}$ content may be ascribed to differences in the raw materials used (clays and sands), to intentional addition by the pottery workshops to produce objects with specific purposes [6,30,31] and/or to circulation of Ca-rich solutions within the pore spaces of the pottery fragments during their burial history [1]. The widespread presence (see BSEM + EDS section below) in both Spanish and Portuguese potsherds under investigation of calcite (rarely dolomite) grains and of well preserved calcareous microfossils (foraminifera of the genus Globigerina) as main constituents of the temper fraction is supportive of the first hypothesis mentioned above. With a view to highlight compositional similarities between Spanish and Portuguese sites, a not so easy task bearing in mind the homogeneity of the used raw materials (estuarine river sediments) which in turn reflects the fairly homogeneous geological background across the Southern Portugal and Spain investigated sites, selected elemental binary and ternary plots have been used. Except for one sample from Santarém (ST20) and one from Monte Molião (MM26), both the ternary diagram $\mathrm{Rb}-\mathrm{Y}-\mathrm{Sr}$ (Fig. 3) and the $\mathrm{Rb} / \mathrm{K}_{2} \mathrm{O}-$ $\mathrm{Sr} / \mathrm{CaO}$ binary diagram (Fig. 4) suggest a geochemical compatibility of the raw materials used in both Spanish and Portuguese samples. Sample

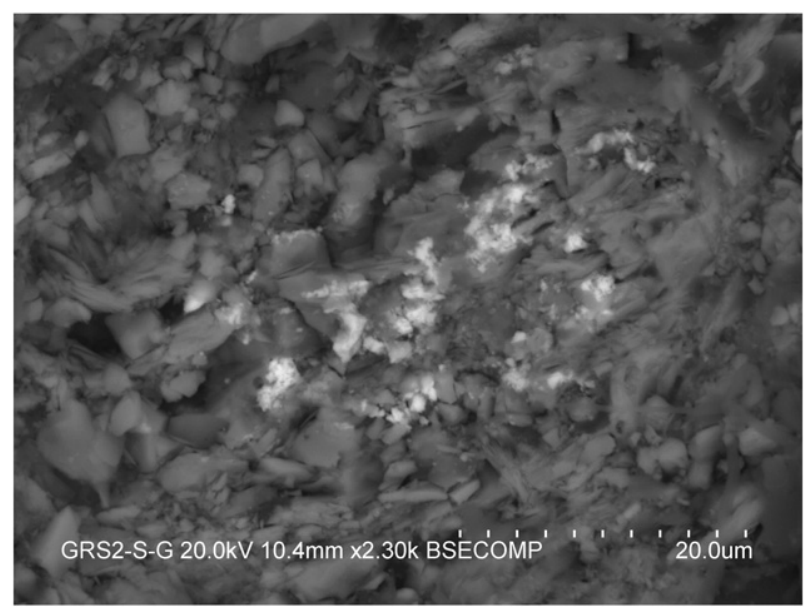

Fig. 7. BSEM + EDS ceramic paste. Scattered micron-size monazite grains within ceramic microfabric from Santarem site.

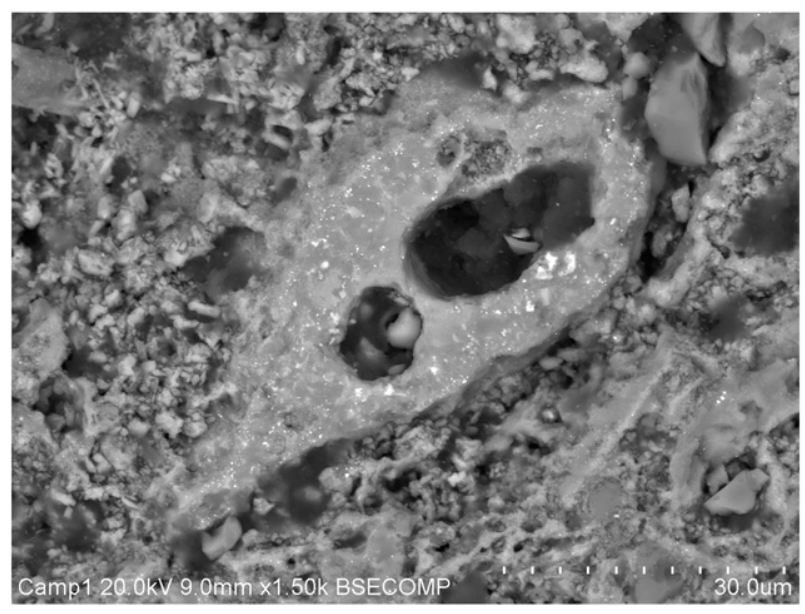

Fig. 8. BSEM + EDS ceramic paste. Planktonic foraminifera fragment with well preserved fossil microstructure from Patio de Banderas site (Seville).

ST20 in fact distinguishes itself for the high Rb content of $227 \mathrm{ppm}$ versus an average value of $69 \mathrm{ppm}$ in the Spanish samples.

\subsection{X-ray diffractometry}

XRD results from 16 samples ( 6 from Patio de Banderas, 1 from Italica, 4 from Santarém, 2 from Castro Marim, 1 from Monte Molião and 2 from Faro) are summarised in Table 2.

Mineralogically, XRD spectra are fairly homogeneous across Andalusian and Portuguese samples. Quartz is confirmed as the main crystalline phase present (abundant to very abundant) together with calcite, feldspars and phyllosilicates (mainly illites with minor illite/smectite and in one case, sample 10 from Patio de Banderas in Seville, smectite). Plagioclase feldspars are always more abundant than K-feldspars, this being especially true in Andalusian samples. Minor dolomite peaks are detectable in both Portuguese (Santarém, Monte Molião but not Faro and Castro Marim) and Patio de Banderas sherd fragments. With regards to kiln firing temperature, the near absence of newly formed "high temperature" mineral phases such as diopside, gehlenite and mullite (diopside has been found only in two samples -sample SEV 7 from Patio de Banderas and sample ST20 from Santarém, together with the presence of well defined peaks belonging to carbonates (calcite and dolomite) and the absence of melting features in phyllosilicates

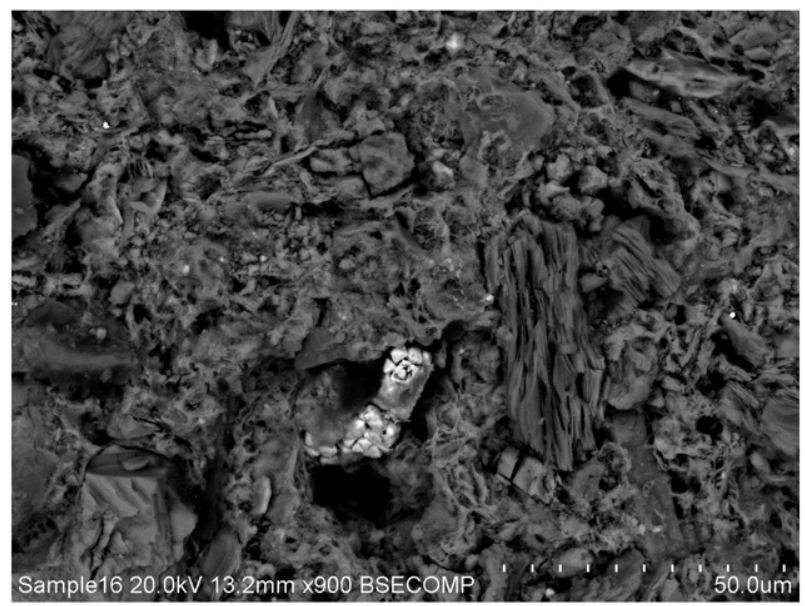

Fig. 9. BSEM + EDS ceramic paste. Illitic laths splitting along cleavage planes due to dehydroxilation processes during firing processes. Hematite crystals also visible (bright). 


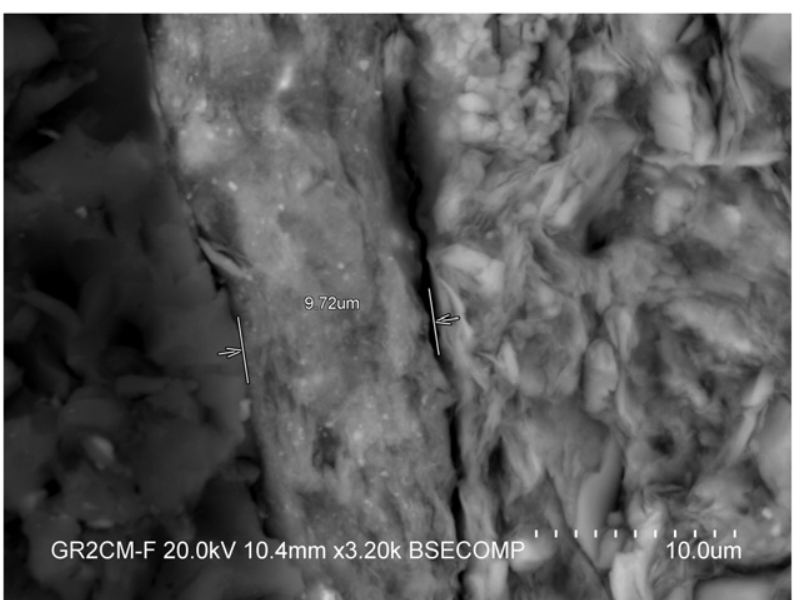

Fig. 10. BSEM + EDS engobe. Interface engobe-ceramic paste.

typical of high temperature firing such as the development of mullite filled nanopores [10] suggests low firing conditions in the kilns $\left(<900{ }^{\circ} \mathrm{C}\right)$. The widespread abundance of illite as the dominant clay mineral species is also in line with this hypothesis and may be used to fix the kiln temperature in the range $>600{ }^{\circ} \mathrm{C}<950{ }^{\circ} \mathrm{C}[2,32]$. Ti (rutile) and Fe oxides (hematite and maghemite) are present in all samples as accessory minerals as well as $\mathrm{Cu}$-oxides (cuprite). The Fe-oxides may represent newly formed phases during the firing process and their coexistence is compatible with pottery manufacturing technique involving atmosphere changes during firing from oxidizing to reducing conditions [10].

\subsection{Scanning-electron microscopy and micro-analysis}

BSEM + EDS analysis has been used to describe the micro-texture of the ceramic paste and its relation with the black engobe surface layer and to identify the presence of individual mineralogical markers which due to their scarcity were undetectable by Portable XRF and XRD analyses.

\subsubsection{Ceramic body}

Under BSEM the ceramic paste in all samples displays a fine-grained microfabric with a bimodal grain-size distribution (Figs. 5,6). While the fine-grained groundmass is constituted by micron-size laths of illite and plagioclase feldspars, the main temper components are mineral grains of quartz and calcite with (in decreasing order of abundance)

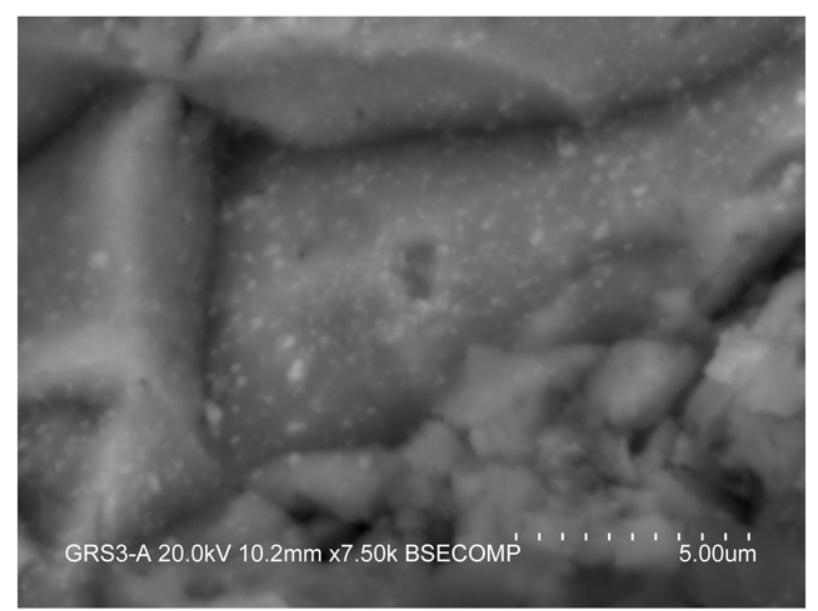

Fig. 11. BSEM + EDS engobe. Micron-size Fe-rich inclusions. titanite, zircon (often zoned), ilmenite, rutile, monazite, hematite and clinopyroxene mineral grains as accessory constituents. In Portuguese samples from Santarém (sample 19) and Castro Marim (sample 18) and in three Andalusian samples (sample 8 from Patio das Banderas in Seville city centre, sample 12 from Italica and sample 16 from Orippo), small inclusions of gold are also found in the temper fraction whereas in two samples from Seville (samples 1 and 7), scattered Pb-rich grains are present. The detection of Au grains in Roman pottery from the Guadalquivir river valley region is not unexpected as gold can be present in alluvial placer deposits used as a pottery raw material source [11]. Pyrite, $\left(\mathrm{FeS}_{2}\right)$ and chalcopyrite $\left(\mathrm{CuFeS}_{2}\right)$ grains were found only in samples from Santarém and Castro Marim. Common temper components, albeit found only as scattered micron-size mineral grains, are also grains of monazite ((Ce,La,Y,Th) $\mathrm{PO}_{4}$; Fig. 7), a phosphate accessory mineral typically found in fluvial deposits in areas characterized by granitic geological substrates such as is the case in the SW Iberian areas under investigation [33]. Microfossils (planktonic foraminifera of the genus Globigerina) are also commonly found with their microstructure still well preserved (Fig. 8): the widespread presence of calcite grains together with the preservation of the fossil outline and microstructure confirms XRD results in suggesting low firing temperatures (between 750 and $900^{\circ} \mathrm{C}$ ). The low firing temperature in the kiln used to produce the "Losanga" pottery under investigation is further confirmed by the absence of bright reaction rims formed by Ca-rich silicate phases (such as diopside, gehlenite and anorthitic plagioclases) which typically form in Ca-rich ceramics when fired at higher temperatures [2]. In terms of microfabric porosity in the temper, fissures at quartz grain boundaries as a result of shrinkage of clay minerals during drying and expansion of quartz crystals from $\alpha$ to $\beta$ phases during firing [10,34] are present, particularly in samples from Andalucia where secondary porosity typically with rounded pores can also be seen. Illitic laths while maintaining their sheet-like typical habit, show separation along basal cleavage planes (Fig. 9), a feature that has been interpreted as a result of de-hydroxylation during low temperature firing processes [10].

\subsubsection{Black gloss}

A fairly continuous and homogeneous vitreous superficial engobe (thickness 13-16 $\mu \mathrm{m}$ ) can be seen on both external and internal parts of all (but one) ceramic fragments (Fig. 10). With respect to the ceramic body, black gloss layers show $\mathrm{Fe}, \mathrm{K}$ and $\mathrm{Al}$ enrichment and $\mathrm{Si}$ and $\mathrm{Ca}$ depletion with scattered micron-size Fe and Fe-Ti inclusions (Fig. 11). The fine grain size of the surface dark coating suggests the application by elutriation of iron oxide-rich clays rather than a varnish as confirmed by the presence of magnetite $\left(\mathrm{Fe}_{3} \mathrm{O}_{4}\right)$, maghemite $\left(\gamma-\mathrm{Fe}_{2} \mathrm{O}_{3}\right)$, and goethite $(\alpha-\mathrm{FeO}(\mathrm{OH})$ in $\mu$-XRD spectra which indicate highly reducing atmosphere and firing temperature not exceeding $850^{\circ} \mathrm{C}$ ). $\mu$-Raman spectroscopy confirmed the presence of magnetite and hematite mineral species.

\section{Conclusions}

The chemical and mineralogical analyses of the tableware Losanga style fragments from Portuguese and Andalusian sites reveal the following common features: a) high Mg-calcite (rarely dolomite) content and high plagioclase/alkali feldspar ratio confirmed both by $\mu$-XRD plots and by Portable XRF (high Sr and low Rb); b) abundance of well preserved planktonic (Globigerinae) foraminifera microfossil fragments; c) widespread presence of illitic as a mineral marker in the groundmass of the ceramic paste; and d) presence of minor mineral markers in the ceramic paste such as monazite (Ce,La,Y,Th) $\mathrm{PO}_{4}$, pyrite $\mathrm{FeS}_{2}$, chalcopyrite $\mathrm{CuFeS}_{2}$, cuprite $\mathrm{Cu}_{2} \mathrm{O}$ and gold.

The mineralogical data of the ceramic paste, in particular the presence of calcite grains, the good preservation of calcitic microfossils and the near absence of secondary newly formed minerals such as diopside, indicate a low technological process involving low firing temperature in the kiln $\left(<900{ }^{\circ} \mathrm{C}\right)$. Small differences between Portuguese and 
Andalusian ceramic fragments (rare presence in one Santarém sample of diopside indicating higher firing $\mathrm{T}$ ) could be related to variable quality standards amongst local workshops.

The multidisciplinary approach adopted in this study which combined archaeological evidence with detailed microchemical, microscopical and mineralogical analyses provided a fast and nondestructive (or microdestructive) tool to add "hard" data towards answering a long lived and still very much alive debate in the archaeology of "Campaniense" pottery production in SW Iberia.

The fairly homogeneous nature of the geological substrate and of the raw materials available in the Portuguese and Spanish sites investigated makes it hard to draw unequivocal conclusions on a common local production of the potsherds in the Guadalquivir. Further research will focus on both expanding the number of investigated sites and refining trace element data using other techniques such as ICP-MS in order to better define trade routes, production technology transfer mechanisms in this important region of the Roman Empire.

\section{Acknowledgements}

The authors would like to thank Prof. Enrique Garcia Vargas for the authorization to sample pottery fragments from the Patio de Banderas site and Dr. Concepción San Martín Montilla Head of the Departamento de Conservación e Investigación of Seville's Archaeological Museum del Museo Archeologico di Sevilla for access to pottery objects from ItalicaPajar de Artillo e Orippo-Cortijo de Tixe.

\section{References}

[1] J. Buxeda, I. Garrigós, V. Kilikoglou, P.M. Day, Chemical and mineralogical alteration of ceramics from the Late Bronze Age kiln at Kommos, Crete: the effect on the formation of a reference group, Archaeometry 43 (2001) 349-371.

[2] G. Cultrone, C. Rodríguez Navarro, E. Sebastián, O. Cazalla, M.J. De la Torre, Carbonate and silicate phase reactions during ceramic firing, Eur. J. Mineral. 13 (2001) 621-634.

[3] P. Mirti, P. Davit, Technological characterization of Campanian pottery of type A, B and $\mathrm{C}$ and of regional products from ancient Calabria (southern Italy), Archaeometry 43 (1) (2001) 19-33.

[4] M.I. Dias, M.I. Prudêncio, On the importance of using scandium to normalize geochemical data preceding multivariate analyses applied to archaeometric pottery studies, Microchem. J. 88 (2008) 136-141.

[5] M.I. Dias, M.I. Prudêncio, M.A. Gouveia, M.J. Trindade, R. Marques, D. Franco, J. Raposo, C.S. Fabião, A. Guerra, Chemical tracers of Lusitanian amphorae kilns from the Tagus estuary (Portugal), J. Archaeol. Sci. 37 (2010) 784-798.

[6] G. Cultrone, E. Molina, C. Grifa, E. Sebastián, Iberian ceramic production from Basti (Baza, Spain): first geochemical, mineralogical and textural characterisation, Archaeometry 53 (2011) 340-363.

[7] N. Forster, P. Grave, N. Vickery, L. Kealhofer, Non-destructive analysis using PXRF: methodology and application to archaeological ceramics, X-Ray Spectrom. 40 (5) (2011) 389-398.

[8] R.J. Speakman, N.C. Littlea, D. Creelb, M.R. Millerc, J.G. Iñañeza, Sourcing ceramics with portable XRF spectrometers? A comparison with INAA using Mimbres pottery from the American Southwest, J. Archaeol. Sci. 38 (12) (2011) 3483-3496.

[9] B.F.O. Costa, A.J.M. Silva, A. Ramalho, G. Pereira, M. Ramos Silva, X-ray compositional microanalysis and diffraction studies of Haltern 70 amphorae sherds, X-Ray Spectrom. 41 (2012) 69-74.

[10] G. Cultrone, E. Molin, A. Arizzi, The combined use of petrographic, chemical and physical techniques to define the technological features of Iberian ceramics from the Canto Tortoso area (Granada, Spain), Ceram. Int. 40 (2014) 10803-10816.
[11] F. Nocete, R. Sáez, M.R. Bayona, J.M. Nieto, A. Peramoa, P. López, J.I. Gil-Ibarguchi, N. Inácio, S. García, J. Rodríguez, Gold in the southwest of the Iberian Peninsula during the 3rd millennium BC, J. Archeol. Sci. 41 (2014) 691-704.

[12] J.J. Ventura Martínez, La cerámica Campaniense en Andalucía Occidental(PhD thesis from Universidad de Sevilla) 1990.

[13] R. de Almeida, Ánforas del Guadalquivir en “Scallabis” (Santarém, Portugal): una aportación al conocimiento de los tipos minoritarios, Collecció Instrumenta, 28, Publicacions i Edicions de la Universitat de Barcelona, Barcelona, 2008.

[14] J. Principal, A. Ribera, El material más apreciado por los arqueólogos. La cerámica fina. La cerámica de barniz negro, Manual de cerámica romana. Del mundo Helenístico al Imperio Romano, Alcalá de Henares: Editores: Comunidad de Madrid, Museo Arqueológico Regional : Colegio de Doctores y Licenciados en Filosofía y Letras y en Ciencias de la Comunidad de Madrid 2013, pp. 43-146.

[15] J. Pimenta, V. Soria, H. Mendes, Cerâmicas de verniz negro itálico e imitações em pasta cinzenta de Monte dos Castelinhos - Vila Franca de Xira, CIRA Arqueologia, 32014 86-121.

[16] M.J. Ramos Suárez, E. García Vargas, Las imitaciones de vajilla de barniz negro itálico en el Bajo Guadalquivir, Comer a la moda - Imitaciones de vajilla de mesa en Turdetania y la Bética occidental durante la antigüedad (s. VI A.C.-VI D.C.), Collecció INSTRUMENTA, 46, Publicacions i Edicions de la Universitat de Barcelona, Barcelona 2014, pp. 239-269.

[17] V. Soria, Cerâmica campaniense a pasta cinzenta em território português, VI Encuentro de Arqueología del Suroeste Peninsular. Villafranca de los Barros, 4-6 octubre de 2012, Villafranca de los Barros: Editor Ayuntamiento de Villafranca de los Barros 2014, pp. 1361-1388.

[18] N. Lamboglia, Per una classificazione preliminare della ceramica campana, in Atti del I Congresso Internazionale di Studi Liguri, Bordighera (1952) 139-206.

[19] C. Alves, R. Mataloto, V. Soria, As produções de imitação da campaniense itálica em pasta cinzenta no Sul do território actualmente português, Actas del II Congresso Internacional da SECAH - Ex Officina Hispana 2 (Braga, 3-6 Abril 2013), tomo I 2014, pp. 113-124.

[20] L. Pedroni, Produzione e diffusione della ceramica calena "media": problemi e ipotesi di lavoro, la ceramica de vernís negre del s s. II i I a.C.: centres productors mediterranis i comercialització a la Peninsula Ibérica, Mataró 2000, pp. 345-362.

[21] L. Pedroni, Ceramica calena a vernice nera, produzione e diffusione, Petruzzi Editore 2001.

[22] J.P. Morel, La céramique à vernis noir du Maroc: une révision, Lixus. Actes du colloque de Larache (8-11 novembre 1989), École Française de Rome, Rome 1992, pp. 217-233.

[23] E. García Vargas, R. Almeida, H. González Cesteros, Los tipos anfóricos del Guadalquivir en el marco de los envases hispanos del siglo I a.C. Un universo heterogéneo entre la imitación y la estandarización, SPAL 20 (2011) 185-283.

[24] P. Berni Millet, Las ánforas de aceite de la Bética y Sua presencia el la Catalunia romana, Publicacions Universitat de Barcelona, Barcelona, 1998.

[25] E. de Sousa, A.M. Arruda, A gaditanização do Algarve, Mainake 32 (2) (2010) 951-974.

[26] M. Tarradell, Los fenicios en Occidente: nuevas perspectivas, Los Fenicios, Barcelona, 1967.

[27] R.J. Speakman, M.S. Shackley, Soil science and portable XRF in archaeology: a response to Frahm, J. Archaeol. Sci. 40 (2) (2013) 1435-1443.

[28] W. Horwitz, L.R. Kamps, K.W. Boyer, Quality assurance in the analysis of foods and trace constituents, J. Assoc. Off. Anal. Chem. 63 (1980) 1344-1354.

[29] Y. Maniatis, M.S. Tite, Technological examination of Neolithic-Bronze Age pottery from central and southeast European and from the Near East, J. Archaeol. Sci. 8 (1981) 59-76.

[30] R.J. Hoard, M.J. O'Brien, M. Ghazavy Khorasgany, V.S. Gopalaratnam, A materialscience approach to understanding limestone-tempered pottery from the Midwestern United States, J. Archaeol. Sci. 22 (1995) 823-832.

[31] N.S. Müller, V. Kilikoglou, P.M. Day, G. Vekinis, The influence of temper shape on the mechanical properties of archaeological ceramics, J. Eur. Ceram. Soc. 30 (2010) 2457-2465.

[32] N. Schiavon, G.A. Mazzocchin, F. Baudo, Chemical and mineralogical characterisation of weathered historical bricks from the Venice lagoonal environment, Environ. Geol. 56 (2-3) (2008) 767-776.

[33] N. Schiavon, G.A. Mazzocchin, The provenance of sand in plasters from Roman wall paintings in the NE of Italy: a chemical mineralogical approach, Open Miner. J. 3 (2009) 32-39.

[34] V. Kilikoglou, G. Vekinis, Y. Maniatis, P.M. Day, Mechanical performance of quartztempered ceramics: part I, strength and toughness, Archaeometry 40 (1998) 261-279. 